\title{
KARAKTERISASI MORFOLOGI TIGA GENUS SERANGGA PENGGEREK (LEPIDOPTERA: PYRALOIDEA)
}

\author{
Gina Dania Pratami ${ }^{1}$, Rika Raffiudin ${ }^{2}$, \& I Made Samudra ${ }^{3}$ \\ ${ }^{1}$ Jurusan Biologi FMIPA Universitas Lampung \\ Jl. Soemantri Brojenogoro No I. Bandar Lampung 35145 \\ ${ }^{2}$ Departemen Biologi FMIPA Institut Pertanian Bogor \\ Gedung Biologi Kampus IPB, Dramaga, Bogor, Jawa Barat 16680 \\ ${ }^{3}$ Balai Besar Penelitian Bioteknologi dan Sumberdaya Genetik (BB Biogen) \\ Jalan Tentara Pelajar No. 3A, Menteng, Bogor Barat, Jawa Barat 16111 \\ E-mail: ginadaniapratami@gmail.com
}

\begin{abstract}
Morphological characterization of three genus of insect borer (Lepidoptera: Pyraloidea). The objective of the research was to characterize the morphological differences of insect borers between Genus Etiella (Pyralidae: Phycitinae), Scirpophaga (Crambidae: Schoenobiinae), and Ostrinia (Crambidae: Pyraustinae). Observed characters were based on external morphology and genitalia. The result showed that Crambidae has praecinctorium in the tympanic organs, while lack of in Pyralidae. Phycitinae had chaetosema, proboscis, cubital pecten and the elongated forewing. Pyraustinae was lack of chaetosema and their forewings are wide towards termen. Whereas, Schoenobiinae had chaetosema with elongated forewing. Etiella had scales on antemedial area and their veins M2-M3 are fused. Forewing of Ostrinia had 11 veins and the corpus bursae shape was round irregular. Forewing of Scirpophaga had 12 veins, anal hair tuft, coremata, and the corpus bursae is round. The main characteristics used in identification at family and subfamily level were the praecinctorium, chaetosema, the shape of the forewings, proboscis, and cubital pecten. Whereas at genus level; anal hair tuft, coremata, and shape of the corpus bursae formed the basis of characterization. The morphological characterization was used to make the key identification of insect borers in Indonesia.
\end{abstract}

Key words: Etiella, external morphology, genitalia, Ostrinia, Scirpophaga

\begin{abstract}
ABSTRAK
Karakterisasi morfologi tiga genus serangga penggerek (Lepidoptera: Pyraloidea). Penelitian ini bertujuan untuk menentukan perbedaan karakter morfologi Genus Etiella (Pyralidae: Phycitinae), Genus Scirpophaga (Crambidae: Schoenobiinae), dan Genus Ostrinia (Crambidae: Pyraustinae) berdasarkan variasi morfologi. Karakterisasi dilakukan dengan pengamatan pada morfologi eksternal dan genitalia. Berdasarkan hasil penelitian, karakter praecinctorium pada organ timpanum dimiliki oleh Crambidae dan tidak dimiliki oleh Pyalidae. Phycitinae memiliki chaetosema probosis dan cubital pecten, serta bentuk sayap depan memanjang. Pyraustinae tidak memiliki chaetosema dan memiliki bentuk sayap depan melebar ke arah termen, sedangkan Schoenobiinae memiliki chaetosema dengan bentuk sayap memanjang. Karakter pada Etiella berupa sisik pada daerah antemedial dan vena M2-M3 yang menyatu. Ostrinia memiliki 11 vena sayap depan dan bentuk corpus bursae yang membulat tidak beraturan. Scirpophaga memiliki 12 vena sayap depan, anal hair tuft, coremata, dan corpus bursae yang berbentuk bulat rapat. Karakter kunci yang digunakan untuk mengidentifikasi tingkat famili dan subfamili adalah ada tidaknya praecinctorium, chaetosema, probosis, dan cubital pecten, serta bentuk sayap depan. Tingkat genus dilihat dari anal hair tuft, coremata dan bentuk corpus bursae. Karakterisasi morfologi dapat dimanfaatkan untuk membuat kunci identifikasi serangga penggerek di Indonesia.
\end{abstract}

Kata kunci: Etiella, genitalia, morfologi eksternal, Ostrinia, Scirpophaga

\section{PENDAHULUAN}

Pyraloidea, salah satu superfamili besar dari Ordo Lepidoptera, memiliki dua famili yaitu Pyralidae dan Crambidae. Serangga dari kedua famili ini merupakan serangga penting tanaman pertanian, karena bersifat menggerek tanaman (Triplehorn \& Johnson, 2005; Solis, 2007). Beberapa spesies serangga penggerek Pyralidae dan Crambidae yang ditemukan pada tanaman pertanian di Indonesia diantaranya adalah penggerek polong kedelai Etiella Zeller (Pyralidae: Phycitinae). Penggerek batang jagung dari Genus Ostrinia Hûbner 
(Crambidae: Pyraustinae) dan penggerek pucuk tebu Scirpophaga Walker (Crambidae: Schoenobiinae) (Solis, 2007).

Karakterisasi morfologi perlu dilakukan untuk mempelajari karakter-karakter kunci yang dimiliki oleh ketiga genera penggerek tersebut, sehingga dapat memberikan ketepatan dalam identifikasi serangga di lapang. Kunci identifikasi Lepidoptera yang ada saat ini adalah kunci identifikasi tingkat famili dalam Ordo Lepidoptera (Nielsen \& Common, 1991; Triplehorn \& Johnson, 2005; Sutrisno \& Darmawan, 2012) dan tingkat Subfamili dari Superfamili Pyraloidea (Sutrisno \& Darmawan, 2012). Belum ada kunci identifikasi untuk serangga penggerek tanaman pertanian khususnya di Indonesia. Oleh sebab itu, berdasarkan karakterisasi morfologi dari penelitian ini diharapkan dapat dibuat kunci identifikasi khusus serangga penggerek tanaman pertanian yang ada di Indonesia.

Serangga penggerek dari Ordo Lepidoptera masih dapat dibedakan secara morfologi hingga tingkat genus. Namun, pada beberapa genus masih memiliki kemiripan sehingga terkadang terjadi kesalahan dalam identifikasi Salah satunya adalah serangga penggerek dari Genus Chilo yang memiliki kemiripan dengan Genus Scirpophaga, terutama pada imago jantan yang ditemukan pada tanaman tebu dan padi (Kalshoven, 1981; Sutrisno \& Darmawan, 2012).

Karakterisasi morfologi dilakukan untuk membedakan karakter atau variasi morfologi, sehingga dapat mengenali serangga secara tepat. Karakter yang digunakan untuk membedakan tingkat famili dalam Ordo Lepidotera diantaranya adalah bentuk dan venasi sayap,tipe antena, organ eksternal pada kepala, serta letak organ timpanum (Triplehorn \& Johnson, 2005). Tingkat subfamili dapat dibedakan bedasarkan karakter eksternal pada kepala, bentuk dan venasi sayap, cubital pecten, serta genitalia. Tingkat genus juga dapat dibedakan berdasarkan karakter morfologi eksternal pada kepala, bentuk abdomen, venasi sayap dan genitalia (Solis \& Mitter, 1992; Sutrisno \& Darmawan, 2012). Penelitian ini bertujuan untuk menentukan perbedaan karakter antara Genus Etiella, Scirpophaga, dan Ostrinia berdasarkan variasi morfologi.

\section{METODE PENELITIAN}

Tempat dan Waktu. Sampel Etiella dan Ostrinia diperoleh dari hasil pemeliharaan di Balai Besar Penelitian dan Pengembangan Bioteknologi dan Sumberdaya Genetik Pertanian (BB-Biogen) Bogor. Sampel Etiella berasal dari Brebes dan Ostrinia dari Bogor, sedangkan Genus Scirpophaga diambil langsung dari Lampung. Contoh spesies yang digunakan untuk ketiga genus tersebut adalah E. zinckenella, $O$. furnacalis, dan $S$. excerptalis. Identifikasi morfologi dilakukan di Laboratorium Entomologi dan Zoologi, Lembaga Ilmu Pengetahuan Indonesia (LIPI), Pusat Penelitian Biologi Cibinong,Jawa Barat. Penelitian ini dilakukan dari bulan Desember 2012 sampai Maret 2013.

Karakterisasi Morfologi Imago. Karakterisasi morfologi fase imago dilakukan pada tingkat famili, subfamili dan genus berturut-turut berdasarkan Solis (2007), Solis \& Mitter (1992); Sutrisno \& Darmawan (2012), Whaley (1973) untuk genus Etiella, Lewvanich (1981) untuk genus Scirpophaga, serta Mutuura \& Munroe (1970) untuk genus Ostrinia. Karakter yang diamati meliputi morfologi eksternal yang terdiri dari morfologi kepala, abdomen, sayap, dan morfologi genitalia (Tabel 1).

Preparasi Venasi Sayap. Preparasi venasi sayap dilakukan berdasarkan metode Robinson (1976) dan Wallenmaier (2007). Preparasi sayap terdiri dari tahap pencucian (washing), pembersihan (clearing), pewarnaan (staining), dan pembuatan slide (mounting). Tahap pewarnaan menggunakan eosin $2 \%$ yang direndam selama satu malam (Lee \& Brown, 2008).

Preparasi Genitalia. Preparasi genitalia dilakukan dengan metode Clarke (1941) dan Robinson (1976). Preparasi genitalia dilakukan untuk imago jantan dan betina yang terdiri dari tahap pencucian, pembersihan, pewarnaan, pemotongan (dissecting) dan pembuatan slide.

\section{HASIL DAN PEMBAHASAN}

Karakter Pembeda Famili Pyralidae dan Crambidae. Berdasarkan hasil karakterisasi, Famili Pyralidae memiliki organ timpanum yang tertutup tanpa adanya praecinctorium, sedangkan Famili Crambidae memiliki organ timpanum yang terbuka dengan adanya pelebaran berupa praecinctorium (Gambar 1). Karakter pembeda tingkat famili ini sesuai dengan Solis (2007) yang membedakan Famili Pyralidae dan Crambidae berdasarkan praecinctorium pada organ timpanum. Praecinctorium merupakan suatu perluasan lubang antromedial pada organ timpanum yang belum jelas fungsinya (Maes,1995; Sutrisno \& Darmawan 2012). Karakter praecinctorium inilah yang menjadi karakter kunci pembeda Famili Pyralidae dan Crambidae. 
Tabel 1. Karakter morfologi untuk karakterisasi tingkat famili, subfamili dan genus

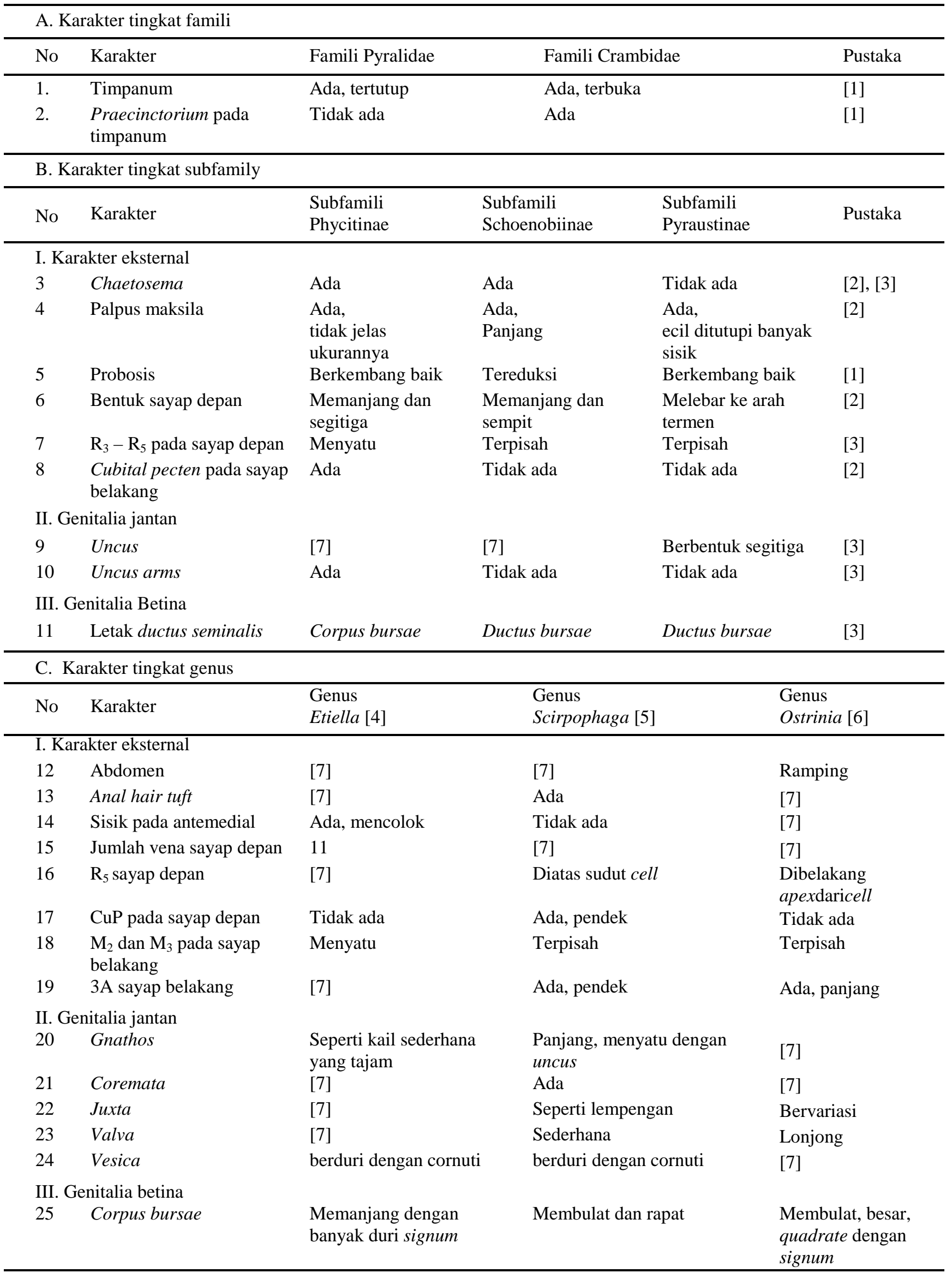

[1]: Solis (2007);[2]: Sutrisno \& Darmawan (2012);[3]: Solis \& Mitter (1992); [4]:Whalley (1973), [5]: Lewvanich (1981), [6]:Mutuura \& Munroe (1970); [7]: studi ini 
Karakter Pembeda Subfamili Phycitinae, Schoenobiinae, dan Pyraustinae. Karakter yang ditemukan pada imago Phycitinae adalah adanya chaetosema (Gambar 2B) dan palpus maksila, tetapi palpus ini tidak jelas ukurannya, probosis berkembang dengan baik (Gambar 3A). Berdasarkan bentuk sayap, subfamili ini memiliki sayap depan memanjang dan berbentuk segitiga (Gambar 4A). Pada sayap belakang terdapat cubital pecten (Gambar 5) dan vena $R_{3}-R_{5}$ sayap depan menyatu (Gambar 6A). Schoenobiinae memiliki chaetosema (Gambar 2B), palpus maksila panjang dan tidak memiliki probosis (Gambar 3B). Bentuk sayap depan memanjang dan sempit (Gambar 4B), tidak ditemukan cubital pecten, dan vena $\mathrm{R}_{3}-\mathrm{R}_{5}$ sayap depan terpisah (Gambar 6B). Pyraustinae memiliki palpus maksila yang kecil, probosis berkembang dengan baik (Gambar 3C), bentuk sayap depan melebar ke arah termen (Gambar $4 \mathrm{C}$ ), dan vena $\mathrm{R}_{3}-\mathrm{R}_{5}$ sayap depan terpisah (Gambar 6C). Namun, Pyraustinae tidak memiliki chaetosema dan cubital pecten.

Bila dilihat dari karakter pembeda berdasarkan probosis, pada Subfamili Phycitinae dan Pyraustinae probosis berkembang dengan baik, sedangkan probosis pada Subfamili Schoenobiinae tereduksi. Karakter tersebut dan karakter pembeda lainnya sesuai dengan laporan Sutrisno \& Darmawan (2012). Karakter vena $\mathrm{R}_{3}-\mathrm{R}_{5}$ sayap depan sesuai dengan uraian Solis \& Mitter (1992). Chaetosema hanya dimiliki oleh Subfamili
A

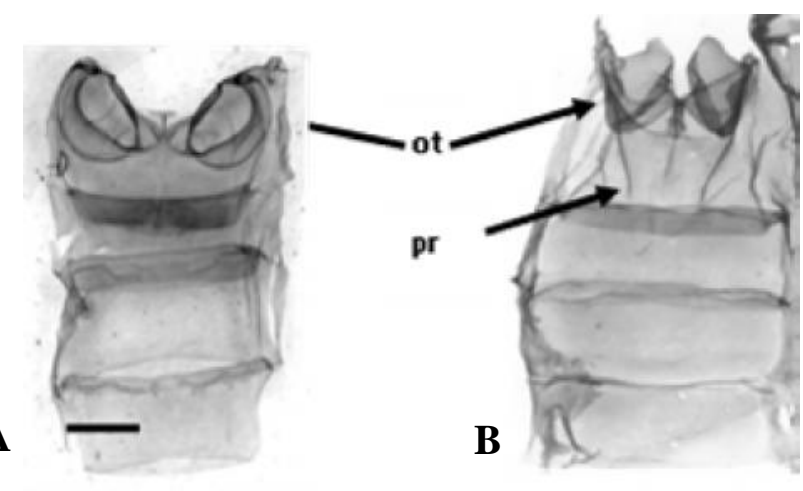

Gambar 1. Perbedaan organ timpanum Pyraloidea. (A) Famili Pyralidae dan (B) Famili Crambidae. ot = Organ timpanum; $\mathrm{pr}=$ praecinctorium. Skala $=1 \mathrm{~mm}$
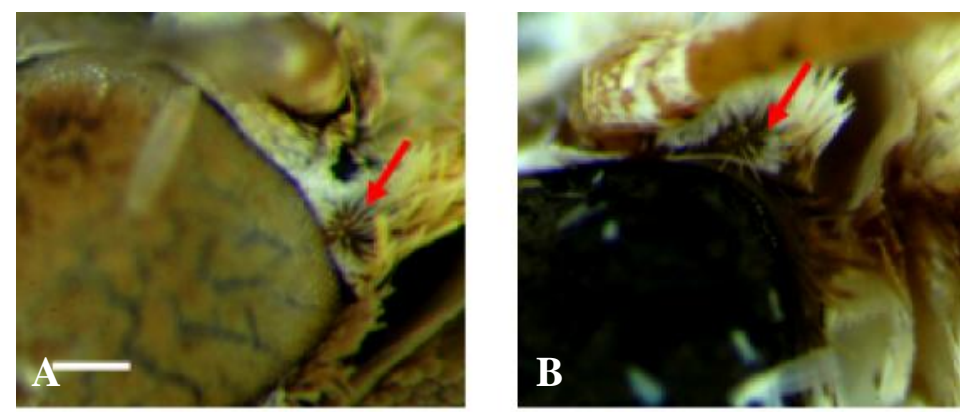

Gambar 2. Chaetosema pada Pyraloidea. (A) Phycitinae dan (B) Schoenobiinae. Skala = 0,5 mm
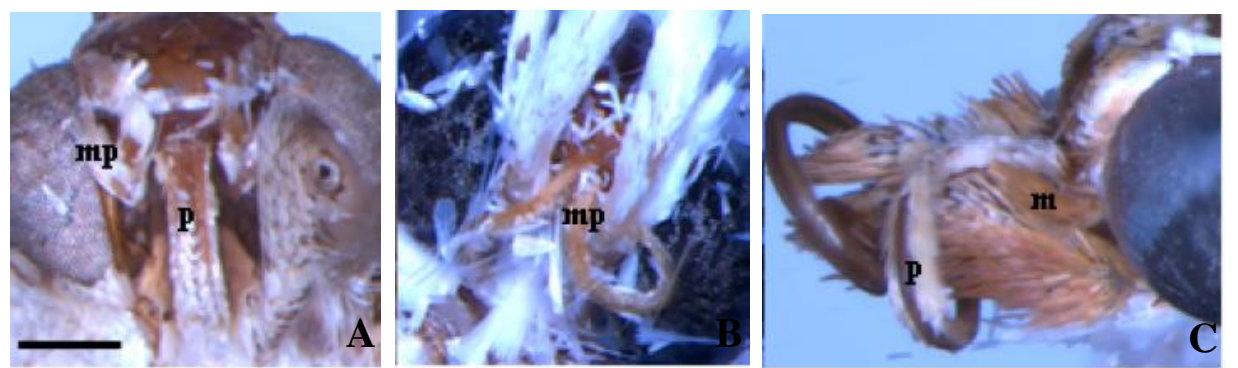

Gambar 3. Karakter maksila palpus dan probosisPyraloidea. (A) Phycitinae (tampak anterior), (B) Schoenobiinae (tampak anterior), dan (C) Pyraustinae (tampak lateral). $\mathrm{mp}=$ maksila palpus; $\mathrm{p}=$ probosis. Skala $=0,5$ $\mathrm{mm}$ 

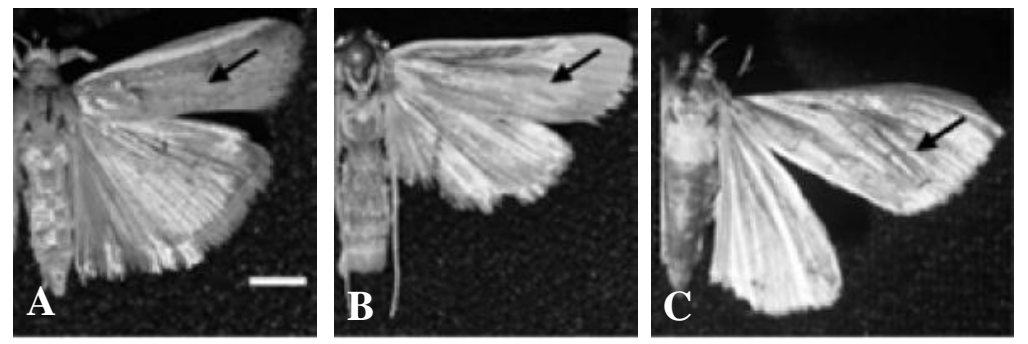

Gambar 4. Karakter bentuk sayap depan Pyraloidea. (A) Phycitinae, (B) Schoenobiinae, dan (C) Pyraustinae. Skala $=2 \mathrm{~mm}$
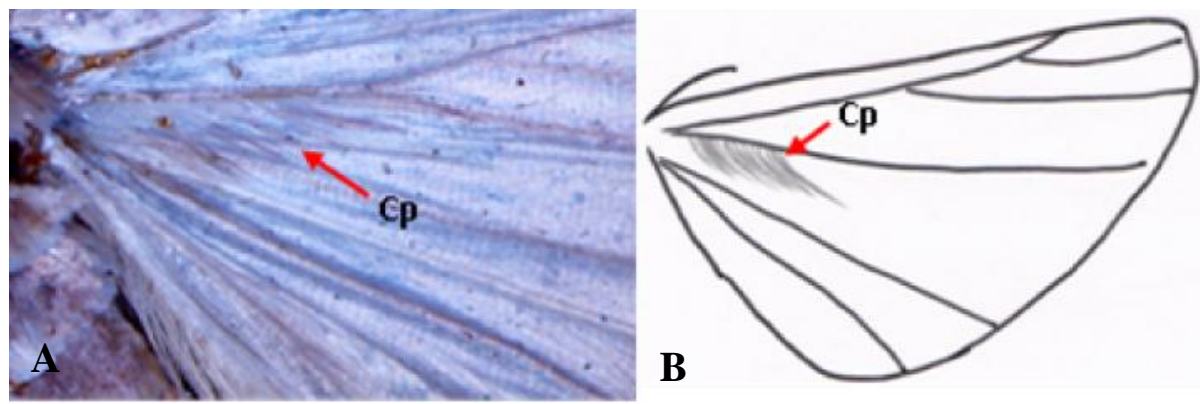

Gambar 5. Karakter Cubital pecten pada sayap belakangPhycitinae. (A) Cubital pecten pada sayap belakang Phycitinae (B) skema cubital pecten pada sayap belakang. $\mathrm{Cp}=$ Cubital pecten. Skala $=1 \mathrm{~mm}$
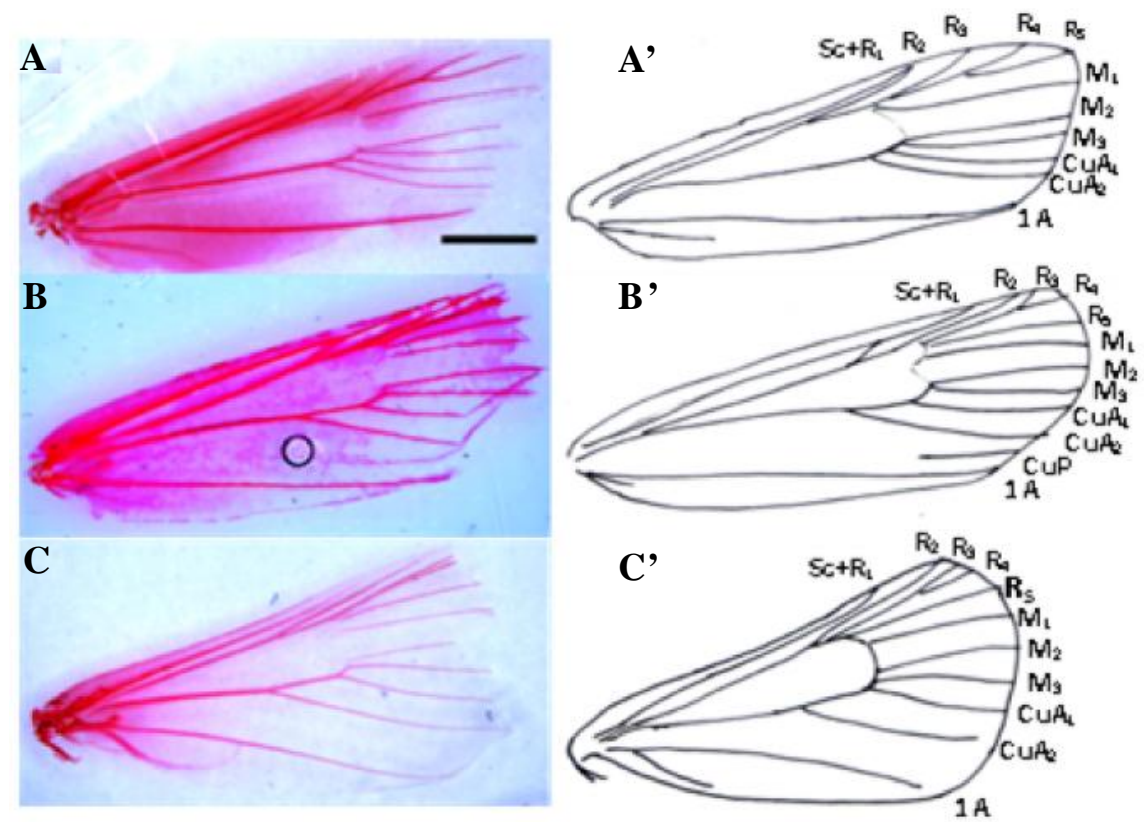

Gambar 6. Karakter venasi sayap depan Pyraloidea. (A-A') Etiella (Phycitinae), (B-B') Scirpophaga (Schoenoebiinae), (B-C') Ostrinia (Pyraustinae). $\mathrm{Sc}=$ subcosta $\mathrm{Rs}=$ radius sektor, $\mathrm{M}=$ median, $\mathrm{CuA}$ $=$ cubital anal, dan $\mathrm{A}=$ anal. Skala $=2 \mathrm{~mm}$ 
Phycitinae dan Schoenobiinae, sedangkan Subfamili Pyraustinae tidak memiliki karakter tersebut. Karakter cubital pecten hanya dimiliki oleh Phycitinae. Dengan demikian, berdasarkan karakterisasi morfologi pada tingkat subfamili, ketiga subfamili ini dapat dibedakan berdasarkan ada tidaknya cubital pecten, probosis, dan chaetosema. Cubital pecten adalah sisik tebal (pecten) yang terdapat pada vena cubital sayap belakang yang terletak dekat pangkal, sedangkan Chaetosema merupakan sisik tegak yang terdapat pada kepala di antara pangkal antena dan oceli (Sutrisno \& Darmawan, 2012).

Berdasarkan genitalia, Phycitinae jantan memiliki uncus yang berbentuk panjang, ramping dan terlihat tajam, serta ditemukan uncusarm. Uncus pada Schoenobiinae terlihat panjang dan ramping, sedangkan Phyraustinae memiliki uncus yang berbentuk segitiga. Pada Schoenobiinae dan Pyraustinae tidak ditemukan uncusarm (Gambar 7). Phycitinae betina memiliki ductus seminalis yang terletak pada corpus bursae, sedangkan pada Schoenobiinae dan Pyraustinae ductus seminalis ini terletak pada ductus bursae (Gambar 8). Karakter pembeda ketiga subfamili tersebut berdasarkan genitalia jantan dan betina sesuai dengan laporan Solis \& Mitter (1992).
Karakter Pembeda Genus Etiella, Scirpophaga, dan Ostrinia. Imago Etiella memiliki abdomen yang sedikit lebih besar dibandingkan dengan kedua genus lainnya (Gambar 9A). Pada daerah antemedial sayap depan ditemukan sisik yang berwarna lebih mencolok (Gambar 10). Sisik ini terlihat seperti garis membujur yang berwana lebih gelap dibandingkan dengan daerah lainnya. Selain itu, Etiella memiliki 11 venapada sayap depan dengan vena $R_{5}$ muncul dari vena $R_{4}($ Gambar 6A) Pada sayap belakang vena $M_{2}$ dan $M_{3}$ terlihatmenyatu, serta vena 3A panjang (Gambar 11A). Karakter yang ditemukan pada Scirpophaga adalah abdomen besar dengan bagian anal tertutup oleh sisik (anal hair tuft) (Gambar 9B). Scirpophaga memiliki vena sayap depan yang berjumlah 12 dengan adanya penambahan vena $\mathrm{CuP}$. Vena $\mathrm{R}_{5}$ muncul diatas sudut cell (Gambar 6bB. Pada sayap belakang, vena $\mathrm{M}_{2}$ dan $\mathrm{M}_{3}$ terpisah, serta vena 3A terlihat lebih pendek (Gambar 11B). Karakter yang ditemukan pada Ostrinia adalah abdomen ramping (Gambar 9C), vena sayap depan berjumlah 11 dengan vena $\mathrm{R}_{5}$ muncul dibelakang apex dari cell (Gambar 6C). Sayap belakang memiliki vena $\mathrm{M}_{2}-\mathrm{M}_{3}$ yang terpisah serta vena $3 \mathrm{~A}$ yang panjang (Gambar 11C) .

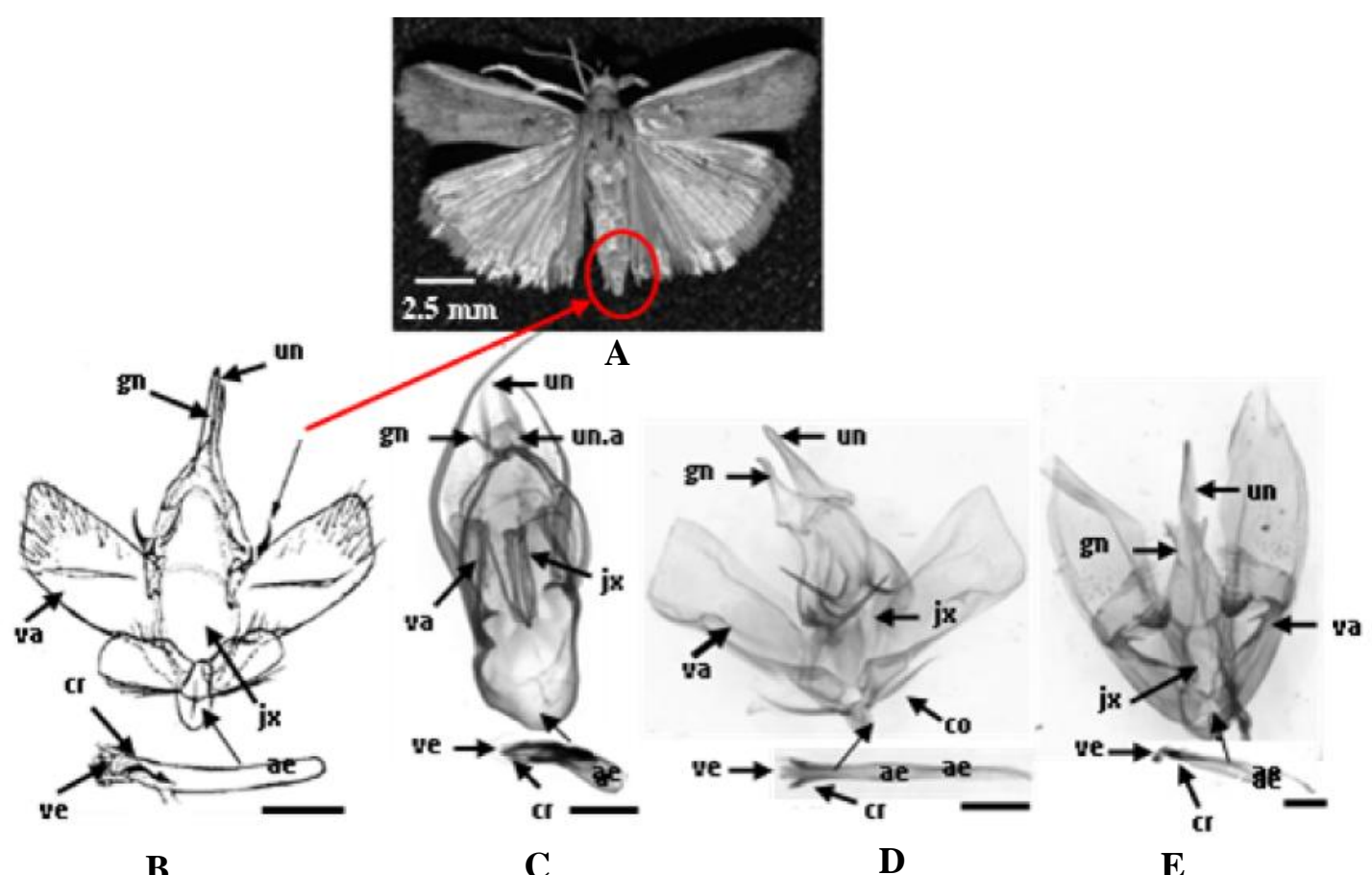

Gambar 7. Karakter pada genitalia jantan Pyraloidea. (A) Imago jantan, (B) skema genitalia jantan (Lewvanich 1981), (C) Etiella(Phycitinae),(D) Scirpophaga (Schoenobiinae), dan (e) Ostrinia(Pyraustinae). un $=$ uncus $;$ un. $\mathrm{a}=$ uncus arm $; \mathrm{gn}=$ gnathos $; \mathrm{jx}=$ juxta $; \mathrm{va}=$ valva $; \mathrm{co}=$ coremata $; \mathrm{ve}=$ vesica $; \mathrm{cr}=$ cornuti; ae $=$ aedeagus. Skala $=1 \mathrm{~mm}$ 


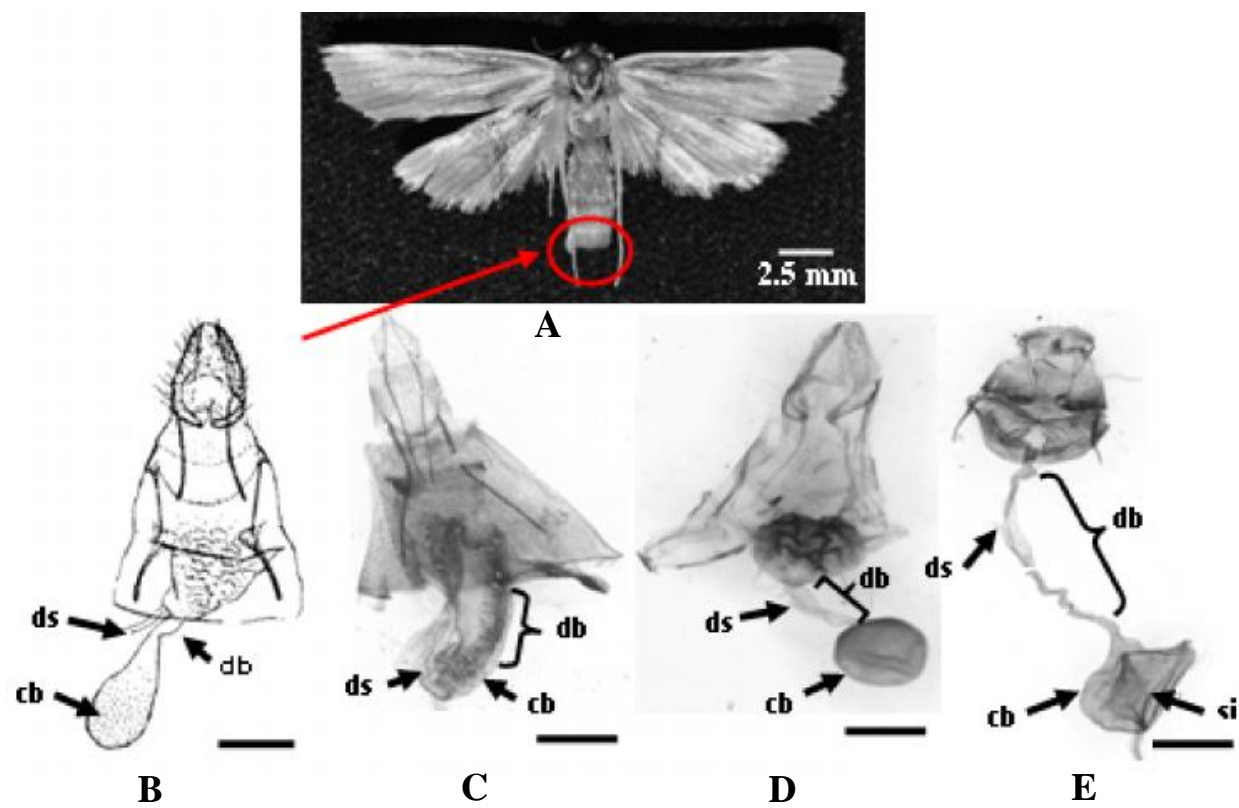

Gambar 8. Karakter pada genitalia betina Pyraloidea. (A) Imago betina, (B) Skema genitalia betina (Lewvanich 1981), (C) Etiella(Phycitinae), (D) Scirpophaga (Schoenobiinae), dan (E)Ostrinia (Pyraustinae) ds $=$ ductus seminalis $; \mathrm{cb}=$ corpus bursae $; \mathrm{db}=$ ductus bursae $; \mathrm{si}=$ signum. $\mathrm{Bar}=1 \mathrm{~mm}$.
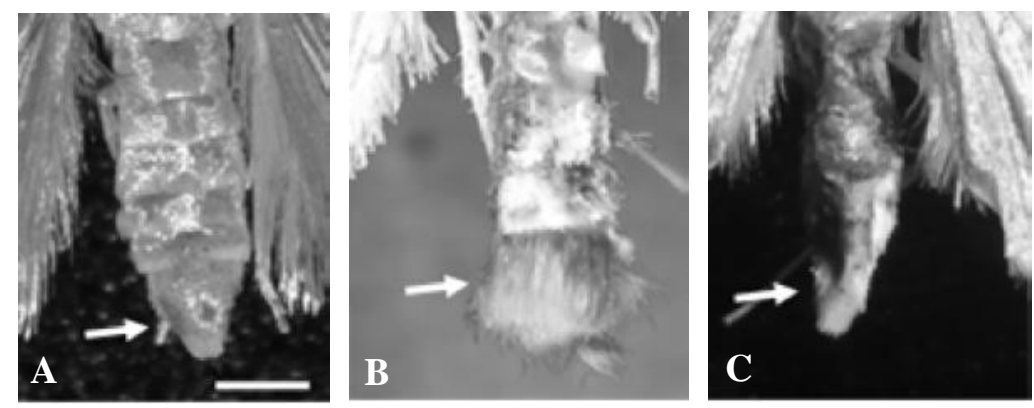

Gambar 9. Karakter bentuk abdomen dan anal hair tuft Pyraloidea (A) Etiella, (B) Scirpophaga, (C) Ostrinia. Bar $=5 \mathrm{~mm}$

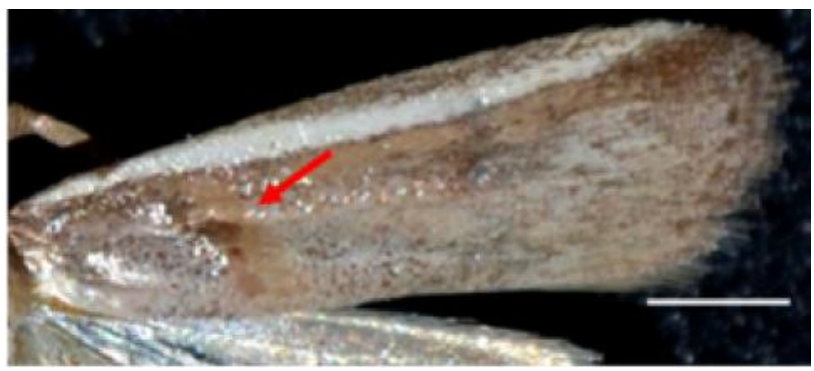

Gambar 10. Karakter sisik pada daerah antemedial sayap depan Etiella. Bar $=2 \mathrm{~mm}$ 

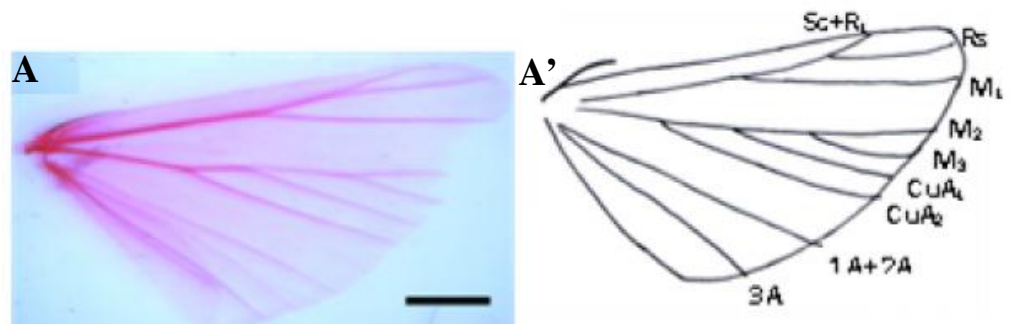

B
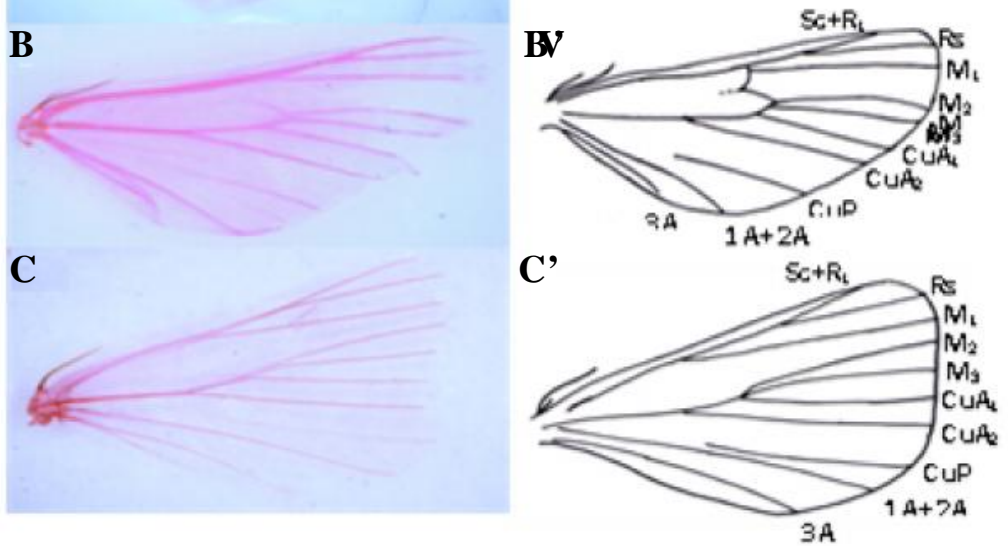

Gambar 11. Karakter venasi sayap belakang Pyraloidea. (A-A') Etiella (Phycitinae), (B-B') Scirpophaga (Scoenoebiinae, (C-C') Ostrinia (Pyraustinae). $\mathrm{Sc}=$ subcosta, $\mathrm{Rs}=$ radius sektor, $\mathrm{M}=$ median, $\mathrm{CuA}$ $=$ cubital anal, dan $\mathrm{A}=$ anal. $\mathrm{Bar}=2 \mathrm{~mm}$

Berdasarkan genitalia jantan(Gambar 7), Etiella memiliki gnathos seperti kail yang tajam, juxta memanjang seperti tabung, valva kecil dan sangat tipis serta pada aedeagus terdapat vesica berduri dengan cornuti. Coremata tidak ditemukan pada genus ini. Scirpophaga memiliki gnathos panjang yang menyatu dengan uncus, juxta seperti lempengan, dan terlihat adanya coremata. Scirpophaga memiliki gnathos panjang yang menyatu dengan uncus, juxta seperti lempengan, dan ditemukan coremata. Genus ini memiliki valva yang sederhana, lebar dan menyatu, pada aedeagus terdapat vesica berduri dengan cornuti yang besar. Ostrinia memiliki gnathos berbentuk segitiga yang menyatu dengan uncus, juxta bervariasi tampak seperti lempengan dan berbentuk melengkung. Valva berbentuk lebar dan lonjong, pada aedeagus terdapat vesica berduri dengan cornuti yang kecil dan banyak, dan tidak terlihat adanya coremata.Aedeagus merupakan bagian dari genitalia jantan yang berada di bagian pangkal dan terletak pada posisi vertikal. Berdasarkan genitalia betina(Gambar 8), Etiella memiliki corpus bursae.Pada Scirpophaga, corpus bursae berbentuk membulat dan rapat, sedangkan pada Ostrinia bagian tersebut membulat tidak beraturan, seperti quadrate dengan duri signum.

Perbedaan karakter tingkat genus dari penelitian ini sesuai dengan Whalley (1973) untuk Etiella, Lewvanich (1981) untuk Scirpophaga, dan Mutuura
\& Munroe (1970) untuk Ostrinia. Karakter pembeda tingkat genus meliputi bentuk abdomen, ada tidaknya anal hair tuft dan sisik pada daerah antemedial, vena $\mathrm{R}_{5}$ dan $\mathrm{CuP}$ sayap depan, vena $\mathrm{M}_{2}-\mathrm{M}_{3}$, dan vena 3A pada sayap belakang. Karakter pada genitalia jantan berupa gnathos, coremata, juxta, valva, dan vesica, sedangkan corpus bursae pada genitalia betina.

Anal hair tuft merupakan rambut-rambut yang tumbuh pada ujung abdomen dan biasanya memiliki warna yang berbeda dengan abdomen. Karakter anal hair tuftdari ketiga genus hanya dimiliki oleh Scirpophaga, sedangkan karakter yang hanya dimiliki Etiella adalah sisik pada daerah antemedial sayap depan. Genus Ostrinia tidak memiliki kedua karakter tersebut. Oleh sebab itu, karakter anal hair tuftdan sisik pada daerah antemedial sayap depan inilah yang dapat menjadi karakter kunci untuk membedakan ketiga genus tersebut.

Kunci Identifikasi Tingkat Famili, Subfamili, dan Genus. Berdasarkan karakterisasi yang telah dilakukan pada tingkat famili, subfamili dan genus, diperoleh kunci identifikasi berdasarkan karakter pembeda morfologi untuk masing-masing tingkat taksa. Kunci identifikasi tingkat famili, subfamili dan genus dari penelitian ini adalah sebagai berikut:

Berdasarkan karakterisasi yang telah dilakukan, karakter kunci untuk mengidentifikasi Famili Pyralidae 


\section{Kunci Identifikasi Genus Etiella, Ostrinia, dan Scirpophaga}

1a Timpanum terdapat pada sternit ruas ke-2 abdomen 2

$1 \mathrm{~b}$ Timpanum terdapat pada toraks (metatoraks)

Famili Noctuidae

2a Timpanum tertutup tanpa praecinctorium .

Famili Pyralidae

2b Timpanum terbuka dengan adanya praecinctorium

Famili Crambidae

3a Chaetosema ada; sayap depan memanjang segitiga atau sempit

4

3b Chaetosema tidak ada; sayap depan melebar ke arah termen ...

Subfamili Pyraustinae

4a Probosis berkembang baik; terdapat cubital pectin pada sayap belakang ........

Subfamili Phycitinae

4b Probosis tereduksi; tidak terdapat cubital pecten pada sayap belakang

Subfamili Schoenobiinae

5a Tidak ada sisik pada daerah antemedial sayap depan; $\mathrm{M}_{2}-\mathrm{M}_{3}$ pada sayap belakang terpisah .....

$5 b$ Terdapat sisik pada daerah antemedial sayap depan; $\mathrm{M}_{2}-\mathrm{M}_{3}$ pada sayap belakang menyatu

6a Vena sayap depan berjumlah 11; tidak terdapat anal hair tuf; tidak ada coremata pada genitalia jantan; corpus bursa pada genitalia betina membulat, tidak beraturan dan terdapat duri signum

6b Vena sayap depan berjumlah 12; terdapat anal hair tuft:terdapat coremata pada genitalia jantan; corpus bursae pada genitalia betina membulat dan rapat

6

\section{Etiella}

Ostrinia

\section{Scirpophaga}

dan Crambidae adalah letak timpanum dan ada tidaknya praecinctorium. Karakter untuk mengidentifikasi tingkat Subfamili Phycitinae, Schoenobiinae, dan Pyraustinae dapat dilihat hanya dari karakter morfologi eksteral. Subfamili Pyraustinae dilihat dari ada tidaknya chaetosema dan bentuk sayap depan. Subfamili Phycitinae dan Schoenobiinae dilihat dari karakter chaetosema, bentuk sayap depan, probosis, dan cubital pecten. Identifikasi Genus Etiella, Scirpophaga dan Ostrinia dapat dilihat berdasarkan ada tidaknya sisik pada daerah antemedial, vena $\mathrm{M}_{2}-\mathrm{M}_{3}$ sayap belakang, jumlah vena sayap depan, ada tidaknya anal hair tuft, coremata (genitalia jantan) dan bentuk corpus bursae (genitalia betina).

Penelitian ini berhasil membuat kunci identifikasi untuk Genus Etiella, Scirpophaga, dan Ostrinia. Karakterisasi morfologi dan kunci identifikasi ini dapat dimanfaatkan sebagai dasar untuk membuat kunci identifikasi serangga penggerek lain yang ada di Indonesia. Kunci identifikasi yang ada saat ini masih umum untuk Ordo Lepidoptera secara keseluruhan, baik di tingkat famili, superfamili, maupun genus. Beberapa kunci identifikasi yang telah ada di antaranya kunci identifikasi tingkat famili dan subfamili dalam Ordo Lepidoptera oleh Triplehorn \& Johnson(2005), tingkat famili dan subfamili Lepidoptera di Australia oleh Nielsen \& Common(1991), dan kunci identifikasi tingkat subfamili di dalam Famili Pyralidae dan inventarisasi genus dari Pyralidae di India oleh Mathew (2006). Di Indonesia, kunci identifikasi yang telah ada ditulis oleh Sutrisno \& Darmawan (2012) pada tingkat famili di dalam Ordo Lepidoptera dan tingkat subfamili dari Superfamili Pyraloidea.

Di Indonesia, belum ditemukan kunci identifikasi khusus serangga penggerek dari Ordo Lepidoptera, sehingga terkadang peneliti mengalami kesulitan pada saat mengidentifikasi serangga penggerek pada tanaman pertanian. Hasil karakterisasi dan kunci identifikasi penelitian ini diharapkan dapat menjadi awal database kunci identifikasi untuk serangga-serangga penggerek yang ada di Indonesia. Selain itu juga kunci ini dapat memberikan informasi dan kemudahan dalam mengidentifikasi serangga penggerek tanaman pertanian secara tepat.

Hasil yang diharapkan dapat dikembangkan dari kunci identifikasi ini adalah kunci identifikasi lengkap untuk serangga penggerek tanaman pertanian di Indonesia, seperti kunci identifikasi tingkat spesies yang telah ada untuk serangga penggerek pada tanaman padi (Khan et al., 1991). Pengembangan terhadap penelitian selanjutnya diharapkan juga dapat menghasilkan kunci identifikasi berdasarkan spesifikasi tanaman inang serangga penggerek. 


\section{SIMPULAN}

Serangga dari Ordo Lepidoptera, Superfamili Pyraloidea adalah serangga penggerek tanaman pertanian yang memiliki keragaman dan variasi pada karakter morfologi.Perbedaan karakter tingkat Famili Crambidae dan Pyralidae dilihat dari praecinctorium pada organ timpanum. Tingkat Subfamili Phycitinae, Schoenobiinae, dan Pyraustinae dapat dibedakan berdasarkan ada tidaknya chaetosema, bentuk sayap depan, ada tidaknya probosis, dan cubital pecten. Perbedaan karakter morfologi tingkat Genus Etiella, Scirpophaga, dan Ostriniadapat dilihat dari ada tidaknya sisik pada daerah antemedial sayap depan, vena $\mathbf{M}_{2}-\mathrm{M}_{3}$ sayap belakang, jumlah vena sayap depan, ada tidaknya anal hair tuft, coremata pada genitalia jantan dan bentuk corpus bursae pada genitalia betina.

\section{SANWACANA}

Terima kasih disampaikan kepada Dr. Hari Sutrisno dan Bpk. Darmawan yang telah membantu dalam proses identifikasi di LIPI. Ucapan terimakasih juga kepada Dr. Sergine Ponsard (Perancis) yang telah membantu dalam mendapatkan buku identifikasi yang berjudul "Taxonomy and distribution of the European corn borer and allied species: genus Ostrinia (Lepidoptera: Pyralidae)".

\section{DAFTAR PUSTAKA}

Clarke JF. 1941. The Preparation of slides of the genitalia of Lepidoptera. Bull.Brooklyn Entomol. Soc. XXXVI(4): 149-161.

Kalshoven LGE. 1981. The Pests of Crops in Indonesia. Laan PA van der, penerjemah. Jakarta: Ichtiar Baru-Van Hoeve.

Khan ZR, Litsinger JA, Barrion AT, Villanueva FFD, Fernandez NJ, \& Taylo LD. 1991. World Bibliography of Rice Stem Borers. Los Banos: International Rice Research Institute.

Lee S \& Brown RL. 2008. Revision of holarctic Teleiodini (Lepidoptera: Gelechiidae). Zootaxa 1818: 1-55.

Lewvanich A. 1981 A revision of the old world species of Scirpophaga (Lepidoptera: Pyralidae). Bull. Br. Mus. Nat. Hist. Entomol. 42(4): 185-298.
Maes KVN. 1995. A comparative morphological study of the adult Crambidae (Lepidoptera, Pyraloidea). B. Annls Soc. Roy. Belge. Entomol. 131: 383434

Mathew G. 2006. An inventory of Indian Pyralids (Lepidoptera: Pyralidae). Zoos Print J. 21(5): $2245-2258$.

Mutuura A \& Munroe E. 1970. Taxonomy and distribution of the European corn borer and allied species: genus Ostrinia (Lepidoptera: Pyralidae). Mem. Entomol. Soc. Can. 102(S71): 1-112.

Nielsen ES \& Common IFB. 1991. Lepidoptera (Moth and Butterflies). In Nauman D (Ed.) The Insect of Australia. Volume 3. Carlton. Melbourne University Press, Victoria.

Robinson GS. 1976. The preparation of slides of Lepidoptera genitalia with special reference to the microlepidoptera. Entomol. Gaz. 27: 127-132.

Solis MA. 2007. Phylogenetic studies and modern classification of the Pyraloidea (Lepidoptera). Rev. Colomb. Entomol. 33(1): 1-9.

Solis MA \& Mitter. 1992. Review and preliminary phylogenetic analysis of the subfamilies of the Pyralidae (sensu stricto) (Lepidoptera: Pyraloidea). Syst. Entomol.17(1): 79-90.

Sutrisno H \& Darmawan. 2012. Series of Indonesian Insects: Moth of Gunung Halimun-Salak National Park. Part 1: Thryridoidea and Pyraloidea. LIPI Press, Bogor.

Triplehorn CA \& Johnson NF. 2005. Boror and Delong's Introductions to The Study of Insects $7^{\text {th }}$ Edition. USA : Thomson Books/Cole.

Wallenmaier TE. 2007. Preparing wing slide for microlepidoptera. Entomological Notes. Michigan Entomological Society. 30. Available at: http:// insects.ummz.lsa.umich.edu/MES/notes/no30.pdf [accesed 9 march 2013].

Whalley PES. 1973. The genus Etiella zeller (Lepidoptera: Pyralidae): a zoogeographic and taxonomic study. Bull. Br. Mus. Nat. Hist. Entomol. 28: 1-65. 